\title{
EVALUATION OF MOSQUITO CULEX QUINQUEFASCIATUS MORTALITY RATE IN THE FACE OF LETHAL CONCENTRATION OF DELTAMETHRIN AND DIAZINON TOXINS
}

\author{
Zeinab HOSSEINNIA *, Reza TARKHANI **, Fatemeh DARABITABAR ***, \\ Mohmmod POORHOSENI **** and Aliakbar HEDAYATI *****
}

* Gorgan University of Agricultural Sciences and Natural Resources, Faculty of Fisheries and Environment, Gorgan, Iran, P. O. Box 219, IR-49316-15581, z.hosseinnia@yahoo.com

** Urmia University, Faculty of Natural Resources, Urmia, Iran, P. O. Box 795, IR-62584-69545, rezat_65@yahoo.com

*** Khorramshahr University of Marine Science and Technology, Faculty of Marine Natural Resources, Khorramshahr, Iran, P. O. Box 669, IR-66741-95326, darabitabar@gmail.com

**** Gorgan University of Agricultural Sciences and Natural Resources, Faculty of Fisheries and Environment, Gorgan, Iran, P. O. Box 219, IR-49316-15581, sm.poorhoseini@yahoo.com

***** Gorgan University of Agricultural Sciences and Natural Resources, Faculty of Fisheries and Environment, Basij Square, Daneshgah Boulevard, Gorgan, Iran, P. O. Box 219, IR-49316-15581, Hedayati@gau.ac.ir

KEYWORDS: pesticide, aquatic insect, $\mathrm{LC}_{50}$, pollution, wetland.

DOI: 10.1515/trser-2017-0012

ABSTRACT

Because of huge consumption for agricultural purpose, presence of pesticides in surface waters of Golestan province (north east of Iran) is very common. These pesticides finally could be stored in aquatic ecosystems and have proven toxic effects on aquatic animals. Culex quinquefasciatus is one of the most common aquatic insects living mainly in the wetlands. The aim of this study was to determine the acute toxicity of deltamethrin and diazinon as potentially perilous organic pesticides and to assess mortality effects of these chemicals on the mosquito Culex quinquefasciatus in the form of $\mathrm{LC}_{50}$.

RÉSUMÉ: Evaluation du taux de mortalité chez Culex quinquefasciatus causé par des concentrations létales de deltamethrine et de diazinone.

A cause de l'utilisation en très grandes quantités de pesticides en agriculture, ces substances sont très fréquemment présentes dans les eaux de surface de la province de Golestan (nord-est de l'Iran). Ces pesticides finissent par se déposer dans les écosystèmes aquatiques, ayant des effets toxiques prouvés sur les animaux aquatiques. Le moustique est un insecte aquatique très commun vivant notamment dans des zones humides. Le but de l'étude a été de déterminer la toxicité aigue de la deltamethrine et de la diazinone, des pesticides organiques potentiellement dangereuses, sous la forme de $\mathrm{LC}_{50}$, sur le moustique Culex quinquefasciatus.

REZUMAT: Evaluarea ratei de mortalitate a țânțarului Culex quinquefasciatus la concentrații letale ale toxinelor deltametrină și diazinonă.

Datorită utilizării în cantități uriașe în agricultură, pesticidele sunt foarte des întâlnite în apele de suprafață din provincia Golestan (nord-estul Iranului). Acestea ajung în final să se acumuleze în ecosistemele acvatice cu efecte toxice dovedite asupra faunei acvatice. Culex quinquefasciatus este una dintre insectele acvatice cel mai des întâlnite, trăind îndeosebi în zonele umede. Scopul acestui studiu a fost determinarea toxicităţii acute a deltametrinei și diazinonei, două pesticide organice potențial periculoase, prin evaluarea mortalității sub forma $\mathrm{LC}_{50}$ induse de aceste substanțe chimice asupra speciei de țâțar Culex quinquefasciatus. 


\section{INTRODUCTION}

There is a growing concern over aquatic contamination because of its harmful effects on biocoenosis structure, biological life including human beings, chemical pesticides with continuous molecules (lengthy half-life cycles) pose a threat to various forms of aquatic life and also to the humans consuming the affected fish (Darko et al., 2008; Curtean-Bănăduc et al., 2016; Sandu et al., 2000). Culex pipiens is a common mosquito that is consumed by fish. Mosquitoes are flying, biting insects that increase in water during their immature phases. It matures from egg to adult in seven days; adults generally live 10-60 days (Langston, 1990).

Presence of pesticide in level waters was reported in North America and Europe since fifty years ago and also, many documents have demonstrated the toxic effects of these contaminants on the aquatic environment (Miller et al., 2002; Galloway and Handy, 2003; Tinoco-Ojanguren and Halperin, 1998; Capel et al., 2001). Organophosphorus pesticides are widely used in agronomy or agriculture, and the aquatic environment near to fields is under penetration of OPs such as diazinon (Tinoco-Ojanguren and Halperin, 1998).

Diazinon (organophosphorus pesticide) possesses moderately persistence constitution and is very used in agriculture (Bazrafshan et al., 2007; Larkin and Tjeerdema, 2000). The diazinon toxicity is due to inhibition of acetylcholinesterase activity, which causes detrimental impacts on non-aim aquatic species close to agricultural fields (Larkin and Tjeerdema, 2000).

Pyrethroids containing deltamethrin are largely used as pediculicides and are among the most potent insecticides (Viran et al., 2003). Pyrethroids are extremely toxic to shrimps and fish and some aquatic arthropods (Viran et al., 2003; Srivastav et al., 1997).

The acute toxicity information provides useful data to determine the action mode and comparison of the amount response among different chemicals. 96-h $\mathrm{LC}_{50}$ experiments are conducted to determine the survival potential of organisms to particular poisonous chemicals. Chemicals with lower $\mathrm{LC}_{50}$ amount are more toxic because lower concentrations result in 50\% of fatality or mortality in organisms.

\section{MATERIAL AND METHODS}

The studied species was Culex quinquefasciatus. Lethal experiments were conducted using 100 individuals. Test chambers were Petri dish. All mosquitows were adapted for two days in these aquaria before assays. Water temperature was regulated at $27^{\circ} \mathrm{C}$. Dead mosquitows were immediately removed to avoid water pollution (Gooley et al., 2000).

Substantial concentrations of active ingredient tested were $0,1,4,10,20,40,100$ and $200 \mathrm{ppm}$ of commercial dose (60\%) for diazinon and 0, 1, 4, 10, 20, 40, 100 and $200 \mathrm{ppm}$ of commercial dose (2.5\%) for deltamethrin. 14 groups (seven for diazinon and seven for deltamethrin) of 100 mosquitos were exposed for 96 hours in the Petri dishes.

During the acute toxicity experiment, the water temperature in Petri dish was $27^{\circ} \mathrm{C}$. There was not food administered during the assay and test media was not renewed. Mortality rates were recorded at 24, 48, 72 and $96 \mathrm{~h}$. Acute toxicity tests carried out according to Hotos and Vlahos (1998). Nominal concentration of diazinon and deltamethrin in 50\% mortality of Culex mosquito was attained by probit analysis in Finney's method within 24 h, 48 h, 72 h, and $96 \mathrm{~h}$ (Finney, 1971) in the maximum-likelihood procedure (SPSS 2002, SPSS Inc., Chicago, Illinois, USA). Lethal concentration value was obtained by graphical interpolation by taking logarithms of deltamethrin and diazinon concentrations versus probit value of percentage mortality and also by fitting a regression equation arithmetically. 
A 95\% confidence limits for LC50 were computed by using the formula:

$$
\left(\mathrm{LC}_{50} 95 \% \mathrm{CL}\right)=\mathrm{LC} 50 \pm 1 / 96\left[\mathrm{SE}\left(\mathrm{LC}_{50}\right)\right]
$$

The SE of $L_{50}$ was determined with formula: $S E(L C 50)=1 / b \sqrt{p n w}$

Where: $\mathrm{b}=$ the gradient of the chemical-probit analyser response (regression) line; $\mathrm{w}=$ the average weight of the observations, $p=$ the number of chemical used, $n=$ the number of animals in each group (Hotos and Vlahos, 1998). After the acute toxicity test, the NOEC (No Observed Effect Concentration) and LOEC (Low Observed Effect Concentration) were calculated for each measured endpoint.

\section{RESULTS AND DISCUSSION}

There was no mortality during the acclimation period before exposure, also there was no mortality in the control group during acute toxicity tests. The mortality of mosquito Culex quinquefasciatus for both of deltametrin and diazinon are in tables 1 and 2 during the exposure times at (24-96 h) respectively. The mortality of mosquito Culex quinquefasciatus increased significantly with increasing concentrations (from one ppm to higher concentrations) for both of diazinon and deltamethrin.

However for both of deltamethrin and diazinon there were 100\% mortality at 200 and higher concentrations within the $96 \mathrm{~h}$ after exposure, and no observed $100 \%$ mortality within the $24 \mathrm{~h}$ (Tabs. 1 and 2).

Table 1: Cumulative mortality of Mosquito Culex quinquefasciatus ( $\mathrm{n}=100$ each concentration) exposed to acute diazinon.

\begin{tabular}{|c|c|c|c|c|}
\hline \multirow{2}{*}{$\begin{array}{c}\text { Concentration } \\
(\mathrm{ppm})\end{array}$} & \multicolumn{4}{|c|}{ No. of mortality } \\
\cline { 2 - 5 } & $24 \mathrm{~h}$ & $48 \mathrm{~h}$ & $72 \mathrm{~h}$ & $96 \mathrm{~h}$ \\
\hline 0 & 0 & 0 & 0 & 0 \\
1 & 0 & 0 & 0 & 6 \\
\hline 4 & 0 & 2 & 8 & 30 \\
\hline 10 & 0 & 3 & 15 & 45 \\
\hline 20 & 0 & 3 & 17 & 48 \\
\hline 40 & 3 & 10 & 29 & 59 \\
100 & 15 & 40 & 73 & 89 \\
200 & 43 & 62 & 100 & 100 \\
\hline
\end{tabular}

Table 2: Cumulative mortality of Mosquito Culex quinquefasciatus $(\mathrm{n}=100$, each concentration) exposed to acute deltamethrin.

\begin{tabular}{|c|c|c|c|c|}
\hline $\begin{array}{c}\text { Concentration } \\
(\mathrm{ppm})\end{array}$ & \multicolumn{4}{|c|}{ No. of mortality } \\
\cline { 2 - 5 } & $24 \mathrm{~h}$ & $48 \mathrm{~h}$ & $72 \mathrm{~h}$ & $96 \mathrm{~h}$ \\
\hline 0 & 0 & 0 & 0 & 0 \\
1 & 0 & 0 & 2 & 4 \\
\hline 4 & 0 & 1 & 5 & 10 \\
\hline 10 & 15 & 31 & 53 & 61 \\
\hline 20 & 37 & 49 & 64 & 73 \\
\hline 40 & 49 & 63 & 69 & 82 \\
\hline 100 & 61 & 83 & 88 & 97 \\
\hline 200 & 80 & 89 & 100 & 100 \\
\hline
\end{tabular}


Median lethal concentrations of (10-90\%) experiment are in tables 3 and 4 . Because mortality (or survival) information were prepared for each exposure concentration in a toxicity test at different exposure durations (24, 48, 72, or 96 hours), data can be designed in other ways; the direct line of best fit is then drawn through the spots. These are time-mortality lines. The $\mathrm{LT}_{50}$ (median lethal survival time) can be computed for each concentration.

Table 3: LC50 (1-99) of diazinon depending on time (24, 48, 72 and 96 h) for Mosquito Culex quinquefasciatus.

\begin{tabular}{|c|c|c|c|c|}
\hline \multirow{2}{*}{ Point } & \multicolumn{4}{|c|}{ Concentration (ppm) $(95 \%$ of confidence limits) } \\
\cline { 2 - 5 } & $24 \mathrm{~h}$ & $48 \mathrm{~h}$ & $72 \mathrm{~h}$ & $96 \mathrm{~h}$ \\
\hline $\mathrm{LC}_{1}$ & $18.8 \pm 0.01$ & - & - & - \\
\hline $\mathrm{LC}_{10}$ & $103.3 \pm 0.01$ & $49.9 \pm 0.01$ & $9.8 \pm 0.02$ & - \\
\hline $\mathrm{LC}_{20}$ & $138.8 \pm 0.01$ & $86.6 \pm 0.01$ & $29.9 \pm 0.02$ & - \\
\hline $\mathrm{LC}_{30}$ & $164.5 \pm 0.01$ & $113.0 \pm 0.01$ & $44.4 \pm 0.02$ & $6.5 \pm 0.02$ \\
\hline $\mathrm{LC}_{40}$ & $186.4 \pm 0.01$ & $135.5 \pm 0.01$ & $56.7 \pm 0.02$ & $19.6 \pm 0.02$ \\
\hline LC $_{50}$ & $\mathbf{2 0 6 . 9} \pm \mathbf{0 . 0 1}$ & $\mathbf{1 5 6 . 6} \pm \mathbf{0 . 0 1}$ & $\mathbf{6 8 . 3} \pm \mathbf{0 . 0 2}$ & $\mathbf{3 1 . 9} \pm \mathbf{0 . 0 2}$ \\
\hline $\mathrm{LC}_{60}$ & $227.4 \pm 0.01$ & $177.7 \pm 0.01$ & $79.8 \pm 0.02$ & $44.2 \pm 0.02$ \\
\hline $\mathrm{LC}_{70}$ & $249.3 \pm 0.01$ & $200.2 \pm 0.01$ & $92.2 \pm 0.02$ & $57.3 \pm 0.02$ \\
\hline $\mathrm{LC}_{80}$ & $274.9 \pm 0.01$ & $226.6 \pm 0.01$ & $106.6 \pm 0.02$ & $72.7 \pm 0.02$ \\
\hline $\mathrm{LC}_{90}$ & $310.5 \pm 0.01$ & $263.3 \pm 0.01$ & $126.7 \pm 0.02$ & $94.0 \pm 0.02$ \\
\hline $\mathrm{LC}_{99}$ & $395.0 \pm 0.01$ & $350.2 \pm 0.01$ & $174.3 \pm 0.02$ & $114.5 \pm 0.02$ \\
\hline
\end{tabular}

Table 4: LC50 (1-99) of deltamethrin depending on time (24, 48, 72 and 96 h) for Mosquito Culex quinquefasciatus.

\begin{tabular}{|c|c|c|c|c|}
\hline \multirow{2}{*}{ Point } & \multicolumn{4}{|c|}{ Concentration (ppm) (95\% of confidence limits) } \\
\cline { 2 - 5 } & $24 \mathrm{~h}$ & $48 \mathrm{~h}$ & $72 \mathrm{~h}$ & $96 \mathrm{~h}$ \\
\hline $\mathrm{LC}_{1}$ & - & - & - & - \\
\hline $\mathrm{LC}_{10}$ & - & - & - & - \\
\hline $\mathrm{LC}_{20}$ & $17.7 \pm 0.01$ & - & - & $2.7 \pm 0.04$ \\
\hline $\mathrm{LC}_{30}$ & $46.2 \pm 0.01$ & $19.3 \pm 0.01$ & $8.3 \pm 0.02$ & $5.2 \pm 0.04$ \\
\hline $\mathrm{LC}_{40}$ & $70.6 \pm 0.01$ & $39.3 \pm 0.01$ & $19.7 \pm 0.02$ & $12.1 \pm 0.04$ \\
\hline LC $_{50}$ & $\mathbf{9 3 . 4} \pm \mathbf{0 . 0 1}$ & $\mathbf{5 8 . 1} \pm \mathbf{0 . 0 1}$ & $\mathbf{3 0 . 3} \pm \mathbf{0 . 0 2}$ & $\mathbf{1 8 . 5} \pm \mathbf{0 . 0 4}$ \\
\hline $\mathrm{LC}_{60}$ & $116.2 \pm 0.01$ & $76.8 \pm 0.01$ & $40.9 \pm 0.02$ & $24.9 \pm 0.04$ \\
\hline $\mathrm{LC}_{70}$ & $140.6 \pm 0.01$ & $96.9 \pm 0.01$ & $52.2 \pm 0.02$ & $31.8 \pm 0.04$ \\
\hline $\mathrm{LC}_{80}$ & $169.2 \pm 0.01$ & $120.3 \pm 0.01$ & $65.5 \pm 0.02$ & $39.8 \pm 0.04$ \\
\hline $\mathrm{LC}_{90}$ & $208.8 \pm 0.01$ & $152.0 \pm 0.01$ & $83.9 \pm 0.02$ & $50.9 \pm 0.04$ \\
\hline $\mathrm{LC}_{99}$ & $302.8 \pm 0.01$ & $230.1 \pm 0.01$ & $127.7 \pm 0.02$ & $77.4 \pm 0.04$ \\
\hline
\end{tabular}

Toxicity Testing Statistical Endpoints are presented in figures 1 and 2. 


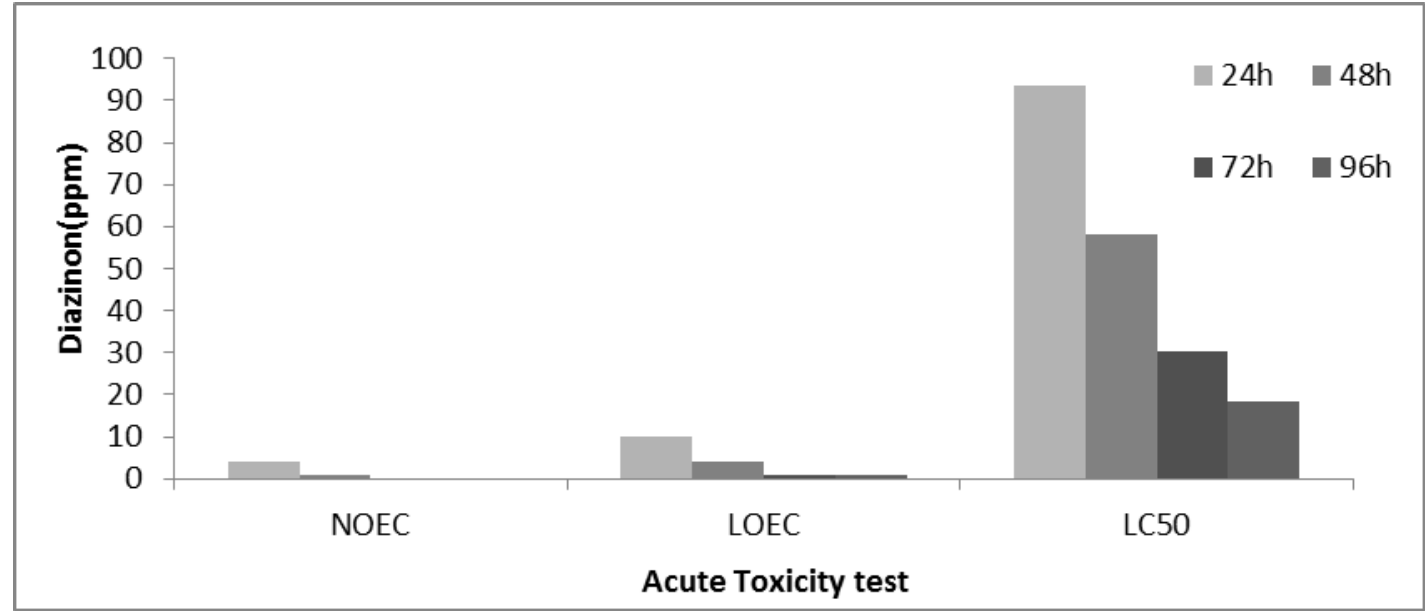

Figure 1: Acute toxicity experimenting statistical endpoints in mosquito Culex quinquefasciatus exposed to Diazinon at different times (24-96 h).

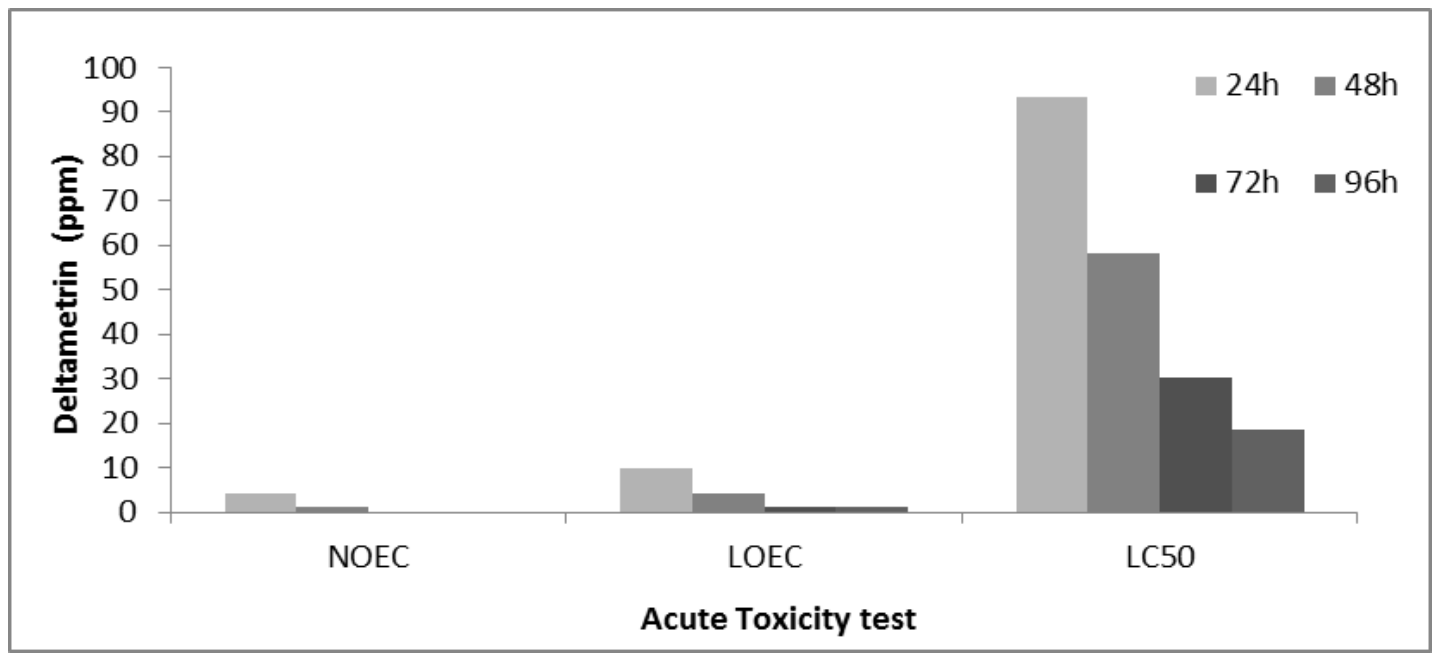

Figure 2: Acute toxicity experimenting statistical endpoints in exposed to deltamethrin at different times (24-96 h).

Incidence of pesticides in high concentrations in agricultural wastewater and their toxicity to aquatic organisms such as fish species have been reported by many researchers (Galloway and Handy, 2003; Capel et al., 2001; Larkin and Tjeerdema, 2000). The effects of the insecticide diazinon and thiacloprid at temperatures 28,30 and $33.5^{\circ} \mathrm{C}$ on the growth of zebra fish eggs Danio rerio, were examined. Results have shown that the toxic effect of diazinon increases further with increasing temperature (Heinz, 2008). Chakabarty and Banergee (1988) calculated and reported the $\mathrm{LC}_{50}$ concentration for diazinon granules equal to five mg per liter (5\%) (Chakabarty and Banergee, 1988). Wege et al. (1999) reported a $99 \%$ mortality for adult male German cockroaches exposed to $30 \mathrm{mg}$ per square meter of active ingredient wettable powder formulation Lambda cyhalothrin on metal surfaces after 30 seconds. The researchers formulation of microcapsules in the same concentration resulted in a mortality of 95\%. The metal surface is a nonabsorbent surface and caused many casualties after 30 seconds of contact with the insect while it develops. (Wege et al., 1999) 
Contamination of water organisms and environment with pesticides via rainfall runoff is very conceivable (Willis and McDowell, 1982). In addition it found that both diazinon and deltamethrin were lethal substrates to mosquito. The mortality of mosquito increased significantly with increasing concentrations (from one ppm to higher concentrations) for both of diazinon and deltamethrin. However for both of deltametrin and diazinon there was $100 \%$ mortality at 200 and higher concentrations within the $96 \mathrm{~h}$ after exposure, and no observed $100 \%$ mortality within the $24 \mathrm{~h}$. The $96 \mathrm{~h} \mathrm{LC}_{50}$ was calculated to be $31.9 \pm 0.02 \mathrm{ppm}$ for diazinon and $18.5 \pm 0.04 \mathrm{ppm}$ for deltamethrin and here it reported that diazinon was lowly toxic to mosquito Culex quinquefasciatus.

LC50 values of aqueous and organic solvent extracts of plants/plant parts on mosquito species reported from tenths to several tens of $\mathrm{mg}^{-1}$ (Raghavendra et al., 2009). Value of diazinon $96 \mathrm{~h} \mathrm{LC}_{50}$ was $0.8 \mathrm{mg} / \mathrm{l}$ for zebra fish (Brachydanio rerio) and it was eight $\mathrm{mg} / \mathrm{l}$ for guppy (Poecilia reticulata) (Adedeji et al., 2008; Keizer et al., 1991). Getaway reaction of unmated and mated nulliparous Aedes aegypti mosquitoes were estimated using three different concentrations of deltamethrin in the presence or absence of a live organism host (Boonyuan et al., 2011). Although deltamethrin is thought to be lower toxic in field conditions due to its adsorption to sediment, these data are useful to potential ecosystem risk evaluation (Viran et al., 2003).

\section{CONCLUSIONS}

Our results showed that $\mathrm{LC}_{50} 96 \mathrm{~h}$ of mosquito Culex quinquefasciatus was calculated to be $31.9 \mathrm{ppm}$ for diazinon and $18.5 \mathrm{ppm}$ for deltamethrin. Maximum allowable concentration was $3.19 \mathrm{mg} / \mathrm{l}$ for diazinon and $1.85 \mathrm{mg} / \mathrm{l}$ deltamethrin respectively. The results of the present study suggest that both chemicals diazinon and deltamethrin varied in their acute toxicity on the mosquito. The toxicity of deltamethrin and diazinon on the mosquito increased with increasing the concentration and exposure time.

\section{ACKNOWLEDGEMENTS}

This work was supported by the Gorgan University of Agricultural Sciences and Natural Resources. 


\section{REFERENCES}

1. Adedeji O. B., Adedeji A., Adeyemo O. K. and Agbede S. A., 2008 - Acute toxicity of diazinon to the African catfish (Clarias gariepinus), African Journal of Biotechnology, 7, 5, 651-654.

2. Bazrafshan E. S., Naseri A. H., Mahvi M. and Shayedhi X., 2007 - Performance evaluation of electrocoagulation process for diazinon removal from aquaeous environments by using iron electrons, Iranian Journal of Environmental Health Science and Engineering, 4, 127-132.

3. Bănăduc D., Moza M. I., Burcea A. and Curtean-Bănăduc A., 2016 - Persistent organic pollutants in continental aquatic ecosystems, in Curtean-Bănăduc A. (ed.), The Impact of persistent organic pollutants on freshwater ecosystems and human health, 95-108, Edit. "Lucian Blaga” University of Sibiu, ISBN 978-606-12-1412-9, 154.

4. Boonyuan W., Kongmee M., Bangs M., Prabaripai A. and Chareonviriyaphap T., 2011 - Host feeding responses of Aedes aegypti (L.) exposed to deltamethrin, Journal of Vector Ecology, 36, 2, 361-372.

5. Capel P. D., Larson S. J. and Winterstein T. A., 2001 - The behavior of thirty-nine pesticides in surface waters as a function of scale, Hydrologica Process, 15, 1251-1269.

6. Chakabarty P. and Banergee V., 1988 - Effect of sublethal toxicity of three organophosforus pesticides on the peripheral hemogrm of the fish Channa punctatus, Enviroment and Ecology, 151-158.

7. Curtean-Bănăduc A., Lyche J. L., Berg V., Burcea A. and Bănăduc D., 2016 - Assessment and monitoring of persistent organic pollutants in lotic ecoszstems - methodological guide, publisher “Lucian Blaga” University of Sibiu, ISBN 978-606-12-1414-3, 117.

8. Darko G., Akoto O. and Oppong C., 2000 - Persistent organochlorine pesticide residues in fish, sediments and water from Lake Bosomtwi, Ghana, Chemosphere, 72, 21-24.

9. Finney D. J., 1971 - Probit Analysis, University Press, Cambridge, 333.

10. Galloway T. and Handy R., 2003 - Immunotoxicity of organophosphorous pesticides, Ecotoxicology, 12, 345-363.

11. Gooley G. J., Gavine F. M., Dalton W., De Silva S. S., Bretherton M. and Samblebe M., 2000 Feasibility of aquaculture in dairy manufacturing wastewater to enhance environmental performance and offset costs, Final Report DRDC Project No. MAF001, Marine and Freshwater Resources Institute, Snobs Creek, 84.

12. Heinz R. K., 2008 - Pesticides thiacloprid and diazinon effects on the embryonic development of zebrafish (Danio rerio), Academic Press, 311.

13. Hotos G. N. and Vlahos N., 1998 - Salinity tolerance of Mugil cephalus and Chelon labrosus, Pisces: Mugilidae/fry in experimental conditions, Aquaculture, 167, 329-338.

14. Keizer J. D., Gostino G. and Vittozzi L., 1991 - The importance of biotransformation in the toxicity of xenobiotics to fish. 1, Toxicity and bioaccumulation of diazinon in guppy (Poecilia reticulata) and zebra fish (Brachydanio rerio), Aquatic Toxicology, 21, 239-254.

15. Langston W. J., 1990 - Toxic effects of metals and the incidence of metal pollution in marine ecosystems, in Firness R. W. and Rainbow P. S. (eds), Heavy Metals in the Marine Environment, CRC Press, Boca Raton, FL, 101-122.

16. Larkin D. J. and Tjeerdema R. S., 2000 - Fate and effects of diazinon, Reviews in Environmental Contamination and Toxicology, 166, 49-82.

17. Miller G. G., Sweet L. I., Adams J. V., Omann G. M., Passino-Reader D. R. and Meier P. G., 2002 - In vitro toxicity and interactions of environmental contaminants (Arochlor 1,254 and mercury) and immunomodulatory agents (lipopolysaccharide and cortisol) on thymocytes from lake trout (Salvelinus namaycush), Fish and Shellfish Immunology, 13, 11-26.

18. Raghavendra K., Singh S. P. and Sarala K., 2009 - Subbarao and Dash, A. P. Laboratory studies on mosquito larvicidal efficacy of aqueous and hexane extracts of dried fruit of Solanum nigrum Linn, Indian Journal of Medical Research, 130, 74-77. 
19. Sandu C., Bloesch J. and Coman A., 2008 - Water pollution in the Mureş Catchment and its impact on the aquatic communities, Transylvanian Review of Systematical and Ecological Research, 6, The Wetlands Diversity, 97-108.

20. Srivastav A. K., Srivastava S. K. and Srivastav S. K., 1997 - Impact of deltamethrin on serum calcium and inorganic phosphate of freshwater catfish, Heteropneustes fossilis, Bulletin of Environmental Contamination and Toxicology, 59, 841-846.

21. Tinoco-Ojanguren R. and Halperin D. C., 1998 - Poverty production, and health: inhibition of erythrocyte cholinesterase via occupational exposure to organophosphate insecticides in Chiapas, Mexico, Archive of Environmental Health, 53, 29-35.

22. Viran R., Erkoc F. U., Polat H. and Kocak O., 2003 - Investigation of acute toxicity of deltamethrin on guppies (Poecilia reticulata), Ecotoxicology and Environmental Safety, 55, 82-85.

23. Wege P. J., Hoppe M. A., Bywater A. F., Weeks S. D. and Gallo T. S., 1999 - A microencapsulated formulation of lambda-cyhalothrin, Proceedings of the 3rd International Conference on Urban Pests, 91-94.

24. Willis G. H. and McDowell L. L., 1982 - Review: Pesticides in agricultural runoff and their effects on downstream water quality, Environmental Toxicology and Chemistry, 1, 267-279. 